f. med. Genet. (1969). 6, 107.

\title{
W. M. Court Brown
}

Michael Court Brown emerged in recent years as one of the most farsighted and dynamic figures in the field of human genetics. Many who have read his recent work on human chromosomes may be unfamiliar with his earlier career, and unaware that he abandoned a successful career in clinical medicine, and later made a switch in his research interests so dramatic (however logical) that few could have contemplated it.

William Michael Court Brown was born in the North of England, near Carlisle, in 1918. $\mathrm{He}$ was educated at Fettes College, Edinburgh, and St. Andrews University where he graduated in medicine in 1942. He specialized in radiotherapy, and after taking the Diploma in Medical Radiology in Edinburgh University joined the staff of the Royal Infirmary of Edinburgh and became a consultant in radiotherapy, a lecturer in radiology in the University of Edinburgh, and deputy director of the Department of Radiotherapy.

His work in clinical radiology stimulated a profound interest in the effect of radiation on man, and in 1950 he joined the external staff of the Medical Research Council at the then Postgraduate School of Medicine of London where he worked at first on the acute effects of radiation. His interest soon shifted to the long-term effects of radiation, and in 1955 together with Dr. J. D. Abbatt he reported an increased incidence of leukaemia among patients who had been treated with $x$-rays for ankylosing spondylitis. This work led to his collaboration with Richard Doll in a study which was urgently required by the Medical Research Council for a government and a nation alarmed by the global effects of the recently exploded hydrogen bomb. This monumental study carried out in less than a year provided a solid factual basis for the association between radiation and leukaemia, and established a simple proportional relation between dose and leukaemia incidence. This latter finding focused attention on the possible deleterious effects of small doses of radiation on large populations. It was for this work that both Court Brown and Doll were awarded the O.B.E. in 1957.

Even at this stage Court Brown believed that the mechanism of leukaemia induction could only be determined by basic studies at the cellular level. He was already conscious of the possible effects of radiation on the genetic material of the cell, and was much influenced by the work of Tjio and Levan on human chromosomes and by the work of Ford on the chromosomes of neoplasms in rodents. Thus when he returned to Edinburgh in 1956 as director of an M.R.C. Group he was already resolved that he would build round him a team of clinicians and biologists who would look for evidence of genetic change in radiation-induced neoplasms in man. 
Soon the technology of human cytogenetics was established, and it was characteristic of Court Brown's approach to research that he would exploit new techniques or findings to the uttermost. This he did with human cytogenetics. His collaboration with Dr. Patricia Jacobs and others produced some of the most important advances in this field, including the first description of an XXY male and of a triple $X$ female, and the recognition of the significance of the XYY male.

Court Brown's vision as early as 1960 led to the development of human cytogenetics in Edinburgh being radically different from that in most other centres. He decided that the work should be principally on defined populations. In this way the relative importance of chromosome aberrations in specific groups such as females with primary amenorrhoea could be determined. This approach also stimulated McLean's work on nuclear sexing of newborn populations, which was the preliminary to the now extensive cytogenetic studies which have been done on normal populations. It was in that latter work that he was most deeply involved at the time of his death. He opened up a field which he termed human population cytogenetics, and which probably has yet to yield its most valuable rewards, e.g. in linkage studies and from the investigation of individuals with abnormal sex chromosome constitutions in relation to human behaviour.

A painstaking attention to accuracy regardless of the amount of work involved was another feature of his approach to research. The massive amount of work he contemplated in the future made it inevitable that he should consider the automation of chromosome analysis, and already major steps have been taken towards this goal. Success in this will be in large measure due to his untiring efforts.

Michael Court Brown was universally respected for his ability and for his refusal to sacrifice principle for expediency. His unusual frankness, in a society accustomed to diplomacy and double think, did not always win him friends, and he also had a shyness which he was never quite able to overcome and which was sometimes taken for indifference. Those closest to him were aware, however, of an exceptional humanity especially in his concern for people as individuals. He will be missed not only as a distinguished scientist but also as a friend and colleague of unusual sensitivity.

D. G. HARNDEN 